\title{
Desoria calderonis sp. nov., a new species of alpine cryophilic springtail (Collembola: Isotomidae) from the Apennines (Italy), with phylogenetic and ecological considerations
}

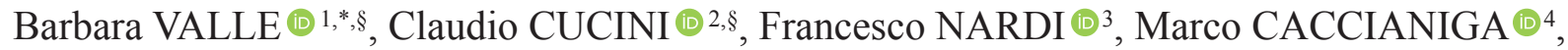

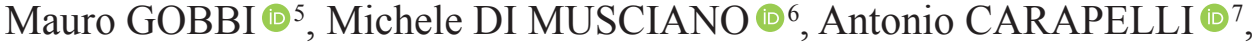 \\ Gentile Francesco FICETOLA ${ }^{8}{ }^{8}$, Alessia GUERRIERI ${ }^{9}{ }^{9} \&$ Pietro Paolo FANCIULLI ${ }^{10} 10$ \\ ${ }^{1,4}$ Department of Biosciences, Università degli Studi di Milano, Via Celoria 26, 20133 Milano, Italy. \\ ${ }^{2,3,7,10}$ Department of Life Sciences, University of Siena, Via A. Moro 2, 53100 Siena, Italy. \\ ${ }^{5}$ Research and Museum Collections Office, \\ Climate and Ecology Unit, MUSE-Science Museum, \\ Corso del Lavoro e della Scienza 3, 38122 Trento, Italy. \\ ${ }^{6}$ Department of Life, Health \& Environmental Science, University of L'Aquila, \\ Piazzale Salvatore Tommasi 1, Coppito, L'Aquila, Italy. \\ ${ }^{8,9}$ Department of Environmental Science and Policy, Università degli Studi di Milano, \\ Via Celoria 10, 20133 Milano, Italy. \\ *corresponding author: barbara.valle@unimi.it \\ 2Email: claudio.cucini@student.unisi.it \\ ${ }^{3}$ Email: francesco.nardi@unisi.it \\ ${ }^{4}$ Email: marco.caccianiga@unimi.it \\ ${ }^{5}$ Email: mauro.gobbi@muse.it \\ 6Email: michele.dimusciano@univaq.it \\ ${ }^{7}$ Email: antonio.carapelli@unisi.it \\ ${ }^{8}$ Email: francesco.ficetola@unimi.it \\ ${ }^{9}$ Email: alessia.guerrieri@unimi.it \\ ${ }^{10}$ Email: paolo.fanciulli@unisi.it
}

\footnotetext{
${ }^{1}$ urn:lsid:zoobank.org:author:CB2F584B-E9D8-4461-A657-7065DC57CB6C

${ }^{2}$ urn:lsid:zoobank.org:author:9234E970-A6D5-4987-A2B2-C0763B90008F

${ }^{3}$ urn:Isid:zoobank.org:author:732EF475-A842-4AB4-9256-4D3923499F6A

${ }^{4}$ urn:lsid:zoobank.org:author:590AA295-B6AA-47BC-8981-833AFC291DCA

${ }^{5}$ urn:lsid:zoobank.org:author:E9F13310-03D5-472C-B001-3381D80E2366

${ }^{6}$ urn:1sid:zoobank.org:author:83435DE5-EC54-4F32-857D-C0CB0DA07FE3

${ }^{7}$ urn:lsid:zoobank.org:author:817100FF-BCDC-4C16-9C2B-C498C66BD9E8

${ }^{8}$ urn:lsid:zoobank.org:author:E053F987-4F85-45EA-9708-FB0651C2F1FE

${ }^{9}$ urn:lsid:zoobank.org:author:C6DBF46F-E618-45EA-8D8A-488F3D984FDB

${ }^{10}$ urn:1sid:zoobank.org:author:B13991B2-54F2-449A-A342-6B756481E4B5
}

$\S$ joint first authors 
VALLE B. et al., A new species of cryophilic springtail (Collembola) from Italy

Abstract. We describe and delimit with integrative taxonomy the new springtail species Desoria calderonis sp. nov. (Collembola: Isotomidae). This cryophilic species is strictly linked to the supraglacial stony debris of the isolated Calderone glacier (Central Apennines, Italy), one of the southernmost glaciers of Europe. Desoria calderonis sp. nov. could belong to the nivalis-complex, a group of European mountain species included in the violacea-group. Genetic analysis (COI mtDNA barcoding) confirms the morphological attribution to the genus Desoria Nicolet in Desor, 1841, but highlights that the genus, in its current definition, is polyphyletic. We specify the peculiar micro-habitat preferences and highlight the threat of extinction for this cryophilic species in the context of the ongoing climate change and subsequent risk of complete disappearance of the glacier.

Keywords. Glacial biodiversity, glacial refugia, peripheral mountains, vanishing glaciers, unknown biodiversity.

Valle B., Cucini C., Nardi F., Caccianiga M., Gobbi M., Di Musciano M., Carapelli A., Ficetola G.F., Guerrieri A. \& Fanciulli P.P. 2021. Desoria calderonis sp. nov., a new species of alpine cryophilic springtail (Collembola: Isotomidae) from the Apennines (Italy), with phylogenetic and ecological considerations. European Journal of Taxonomy 787: 32-52. https://doi.org/10.5852/ejt.2021.787.1599

\section{Introduction}

Cryophilic springtails (Hexapoda: Collembola) are cold- and moisture-requiring organisms, whose typical habitat is near or above ice or snow (Deharveng et al. 2008; Fjellberg 2010; Buda et al. 2020; Valle et al. 2020; Jureková et al. 2021). Desoria saltans Nicolet, 1841 (Entomobryomorpha: Isotomidae) is among the best known cryophilic springtails and is commonly known as the "glacier flea". This species was already cited by the Italian geologist Stoppani in his early essay "Il Bel Paese" (Stoppani 1876) for its showy, swarming and large assemblages on Alpine glaciers. Nowadays there are indications that "glacier fleas" include multiple taxa of cryophilic Isotomidae related to the genus Desoria: Desoria Nicolet in Desor, 1841, Gnathisotoma Cassagnau, 1957 and Myopia Christiansen \& Bellinger, 1980 (Najt 1981; Fjellberg 2010). These organisms appear to be differentiated among isolated glacial areas (Deharveng 1975; Lauga-Reyrel \& Lauga 1995). By comparing different European glacier forelands, Hågvar et al. (2020) observed how the species belonging to this group, and to a few other pioneer genera, are important not only as components of supraglacial communities (see also Gobbi et al. 2021), but also as early colonisers of recently-deglaciated terrains. High diversity of cryophilic Isotomidae was observed in southern Alaska and in the Canadian Rocky Mountains in North America (Fjellberg 2010). Therefore, we can assume high diversity of the genera related to Desoria at similar sites in Europe.

The genus Desoria comprises 101 described species (Bellinger et al. 1996-2021), mostly distributed in the Holarctic, especially at high latitudes (Potapov 2001). Desoria differs from the closely related genus Isotoma Bourlet, 1839 by the number of apical setae on tibiotarsi (11, with the exception of the pjasini-group), and the absence of ventroapical spine-like setae on the manubrium (Potapov 2001; Fjellberg 2007). From the ecological point of view, Desoria also differs from Isotoma by being more frequent at cold and wet sites and thus including many hygrophile and cold-adapted species (Potapov 2001). Species belonging to the genus Desoria overwinter in the adult stage and are often active on snow or ice, on which they feed (Hao et al. 2020) and migrate (Hågvar 2000; Zhang et al. 2017). Among these cold-adapted species, Desoria and taxonomically related genera like Agrenia Börner, 1906, Gnathisotoma, Myopia and Kaylathalia Stevens \& D'Haese, 2016 (Najt 1981; Fjellberg 2010; Stevens \& D’Haese 2017) include cryophilic species (Potapov 2001; Fjellberg 2007, 2010). Cryophilic species, in particular, are of great interest because they are particularly threatened by the current global warming and are good candidates as indicators for conservation projects aimed at investigating refugial glaciated areas (Gobbi et al. 2021). 
Several works carried out on alpine cryophilic springtails (e.g., Deharveng 1975; Najt 1981; Lauga-Reyrel \& Lauga 1995; Fjellberg 2010; Makowska et al. 2016; Hittorf 2017; Buda et al. 2020) indicated a significant knowledge gap on springtail biodiversity in glaciated areas of the World. The cryophilic collembolan fauna is still poorly described especially from Southern Europe, where it should be particularly differentiated in relation to the glacial history of the peripheral and southernmost European massifs (Deharveng 1975; Najt 1981; Lauga-Reyrel \& Lauga 1995). Furthermore, the taxonomy of Desoria is still uncertain, as both morphological and genetic evidence indicates that this genus is polyphyletic, as it includes different subgroups (Stevens et al. 2006; Fjellberg 2007; Stevens \& D’Haese 2017).

In this work, we present a description of a new species of Desoria found in one of the southernmost European relict glacial areas, the Calderone glacier (Central Apennines, Italy; Grunewald \& Scheithauer 2010). This species is thus a good indicator of a "cold-spot" of the local glacial biodiversity (Cauvy-Fraunié \& Dangles 2019) in the Mediterranean region. In order to provide a robust taxonomic classification for this new species, we applied both morphological and genetic approaches, to obtain a phylogenetic framework. In addition, we provide remarks on its habitat and microhabitat preferences.

\section{Material and methods}

\section{Study area and data collection}

Specimens were collected by the flotation method (Marshall et al. 1994) on the Calderone glacier. The Calderone glacier is located on the Gran Sasso Massif, in the Central Apennines (Italy, Abruzzo; $42^{\circ} 28^{\prime} 16.4^{\prime \prime} \mathrm{N}, 13^{\circ} 34^{\prime} 01.4^{\prime \prime} \mathrm{E}$ ). Presently, it is classified as glacieret (total surface $<0.04 \mathrm{~km}^{2}$; Smiraglia \& Diolaiuti 2015) and it is almost totally covered by stony debris. We searched for Desoria calderonis sp. nov. in all glacial environments, on the supraglacial debris and on the Little Ice Age (LIA) moraines. In order to better verify its distribution, both flotation and pitfall trap methods were used for 15 sampling points on the supraglacial debris as well as 6 sampling points on LIA moraines as controls. In order to better characterize the ecology of Desoria calderonis sp. nov., we recorded micrometeorological (temperature and humidity) and soil data of its habitat and of the surrounding habitat where it was not found, in particular:

- temperature was recorded on supraglacial debris by 15 and on LIA moraines by 2 dataloggers (iButton 1922) for the period 9 July 2020 - 27 July 2021; using this data, we calculated the mean annual temperature, the mean temperature during the snow-free period, the minimum and the maximum temperatures and the duration of the snow-cover;

- relative humidity was recorded in both environments by a datalogger (Tinytag Plus) for the same period; with this data we calculated the mean annual value and the mean value during the snow-free period; - soil samples were collected for 15 points on the supraglacial debris and 6 points on LIA moraines. In soil samples we measured the value of carbonate calcium content, organic matter content and $\mathrm{pH}$.

All dataloggers were positioned $10 \mathrm{~cm}$ under the surface.

\section{Specimen conservation and preparation}

Specimens ( 1 holotype and 15 paratypes), preserved in $90 \%$ ethanol at $-20^{\circ} \mathrm{C}$, were initially cleared by a short immersion in $10 \% \mathrm{KOH}$ solution and then mounted on slides using lactic acid or Marc André as a preservative solution. Additional specimens (five) were prepared for scanning electron microscopy: they were completely dehydrated in absolute ethanol, before critical point drying in a Balzers Union (FL-9496) apparatus and the subsequent sputter coating with gold in an Edwards Sputter Coater S150B. Morphological observations were performed with a Leica Laborlux S light microscope and a Quanta400 (FEI) scanning electron microscope.

\section{Molecular analysis}

Whole genomic DNA was extracted from 10 specimens, individually, using the Wizard ${ }^{\circledR}$ SV Genomic DNA Purification System (Promega, Madison, WI, USA). The mitochondrial marker analyzed-cytochrome $c$ 
VALLE B. et al., A new species of cryophilic springtail (Collembola) from Italy

oxidase subunit 1, 5P fragment (coxl) - was amplified with a universal primer pair (Folmer et al. 1994). PCRs were prepared in a $25 \mu \mathrm{L}$ reaction volume containing: $2.5 \mu \mathrm{L}$ of whole genomic DNA, $1.25 \mu \mathrm{L}$ of both forward and reverse primers $(10 \mu \mathrm{M}), 2.5 \mu \mathrm{L}$ of $\mathrm{MgCl}_{2}(2.5 \mathrm{mM}), 2.5 \mu \mathrm{L}$ of deoxynucleotides (dNTPs, $10 \mathrm{mM}$ ), $5 \mu \mathrm{L}$ of Green GoTaq Flexi Buffer (Promega, Madison, WI, USA), $0.125 \mu \mathrm{L}$ of GoTaq ${ }^{\circledR}$ G2 Flexi DNA Polymerase (Promega, Madison, WI, USA), $5 \mu \mathrm{L}$ and $9.875 \mu \mathrm{L}$ of ddH $\mathrm{H}_{2} \mathrm{O}$. Amplifications were run on a GeneAmp ${ }^{\circledR}$ PCR System 2700 (Applied Biosystems, Foster City, CA, USA) thermal cycler with the following conditions for each of the 35 cycles: a denaturation step at $95^{\circ} \mathrm{C}$ for $1 \mathrm{~min}$, an annealing step at $50^{\circ} \mathrm{C}$ for $1 \mathrm{~min}$ and an elongation step at $60^{\circ} \mathrm{C}$ for $90 \mathrm{~s}$. An additional initial denaturation step was set at $95^{\circ} \mathrm{C}$ for $5 \mathrm{~min}$ as well as a final extension step at $72^{\circ} \mathrm{C}$ for $7 \mathrm{~min}$. PCR products were purified with the kit Wizard ${ }^{\mathbb{B}}$ SV Gel and PCR Clean-up System (Promega, Madison, WI, USA) and sequenced on both strands using a DNAAnalyzer ABI 3730 at Biofab (Rome, Italy). Sequences were then manually corrected and assembled in Sequencher ver. 4.2.2 (Gene Codes, Ann Arbor, MI, USA).

\section{Phylogenetic analysis}

Given the current uncertainties on the monophyly of the genus Desoria (Stevens et al. 2006; Stevens \& D'Haese 2017) and of its closest relatives, a preliminary analysis was conducted to identify Desoria as well as phylogenetically related sequences in order to bypass the assumption of a monophyletic Desoria in the process of taxa selection. All records belonging to the family Isotomidae were downloaded from the BOLD database (Ratnasingham \& Hebert 2007) with their metadata (last download 30 June 2021). The 8483 records were filtered to retain only those including information for the COI-5P cox 1 fragment and having an assigned bin. The longest sequence for each bin was extracted using the $\mathrm{R}$ package 'bold' (ver. 1.2.0, written by Scott Chamberlain) and used as representative for the bin in the following analysis. For all records, metadata associated with a specific bin were revised to identify the taxonomic attribution(s), if available, of each bin, whereas bins with no taxonomic information below the family level in any sequence were discarded. Records were associated with 728 bins in BOLD, 348 of which included sequences with at least some associated taxonomic information. After the addition of the new species, D. calderonis sp. nov.(mean uncorrected divergence within the species is $0.4 \%$, S.D. 0.2), the total dataset was composed of 349 sequences by 438 aligned positions ( $1^{\text {st }}$ and $2^{\text {nd }}$ positions only). The dataset was aligned with MAFFT (Katoh 2002) in order to calculate both uncorrected p-distances and phylogenetic relationships. These latter were obtained, using $1^{\text {st }}$ and $2^{\text {nd }}$ codon position data set, by IQTREE (ver. 1.6.12, default settings with 1000 fast bootstrap replicates and the model was optimized using ModelFinder; Nguyen et al. 2015). A reasonably supported node (bootstrap 92) was identified, including all Desoria sequences - with the exception of Desoria trispinata ( 3 bins, 18 sequences) and Desoria tshernovi (1 bin, 1 sequence, unrelated to 6 D. tshernovi sequences within the node) - as well as sequences from other genera. This subdataset, inclusive of related species and three outgroups (Cryptopygus terranovus, Parisotoma notabilis and Folsomia quadrioculata, grouping outside the Desoria cluster), accounted for 89 sequences by 438 aligned positions and was reanalyzed as above to investigate the phylogenetic position of the new species in the context of Desoria and related species. Once a final phylogenetic tree had been obtained, records that appeared phylogenetically related to D. calderonis sp. nov. were further revised in the BOLD database metadata or in the original literature to assess the existence of ecological and/or phylogeographic similarities.

Abbreviations used in the text
$\begin{array}{ll}\text { Abd } & =\text { abdominal segment } \\ a c c p \text {-setae } & =\text { accessory p-row } s \text {-setae } \\ a l \text {-setae } & =\text { antero-lateral } s \text {-setae } \\ \text { Ant } & =\text { antennal segment } \\ \text { AOIII } & =\text { antennal organ III } \\ a s \text {-setae } & =\text { anterosubmedial } s \text {-setae }\end{array}$




$\begin{array}{ll}\mathrm{bl} & =\text { basolateral field (mentum) } \\ \mathrm{bm} & =\text { basomedian field (submentum) } \\ m s \text {-setae } & =\text { micro } s \text {-setae } \\ \mathrm{PAO} & =\text { post antennal organ } \\ \mathrm{Px} & =\text { proximal field } \\ \mathrm{Th} & =\text { thoracic segment } \\ \mathrm{Tita} & =\text { tibiotarsus } \\ \mathrm{VT} & =\text { ventral tube }\end{array}$

\section{Results}

Phylum Arthropoda Latreille, 1829

Class Collembola Lubbock, 1870

Order Entomobryomorpha Börner, 1913

Family Isotomidae Schäffer, 1896

Subfamily Isotominae Schäffer, 1896

Genus Desoria Nicolet in Desor, 1841

Desoria calderonis Valle sp. nov.

urn:lsid:zoobank.org:act:1DEC543F-66C5-4556-B5B3-6806CEB35488

Figs 1-5

\section{Diagnosis}

Desoria calderonis sp. nov. belongs to the violacea-group sensu Potapov, 2001, with quadridentate mucro without seta, maxillary palp bifurcate, apical folds on labrum sharp. Differences from closely related species are analysed in the section 'Taxonomic and ecological consideration'.

\section{Etymology}

The epithet of the new species reflects the name of the site from which holotype and paratypes derive, Calderone glacier (Italy, Abruzzo, Gran Sasso massif).

\section{Material examined}

\section{Holotype}

ITALY • ; A Abruzzo (Central Italy), Gran Sasso massif, Apennines, Calderone Glacier, supraglacial stony

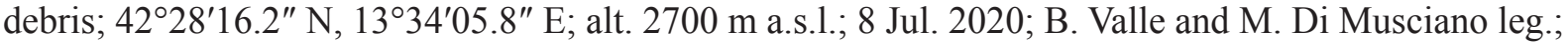
collected with flotation method; Genbank (NCBI) MZ686962-70; Collembola collection, Department of Life Sciences, University of Siena, Italy.

\section{Paratypes}

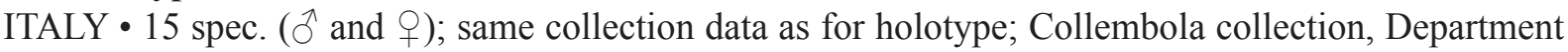
of Life Sciences, University of Siena, Italy.

\section{Description}

BoDy. Mean body length. $1.5 \mathrm{~mm}$ (standard deviation: $0.1 \mathrm{~mm}$ on 12 specimens, see Table 1). Colour violet-black on abdomen and antennae, lighter on furca and legs, which are brownish (Fig. 1); juveniles are much paler, bluish. Cuticle granulation fine and regularly distributed; all dorsal tergites clearly separated from each other. Abd. III and IV of approximately same width.

Chaetotaxy. Terga plurichaetotic, consisting of micro-, meso- and macrosetae, these latter well differentiated on last abdominal tergites (Abd. IV-VI, in median position), but not well distinguished 
from ordinary setae on other tergites (Fig. 2A). On every segment, longer setae concentrated along the lateral and posterior edges of tergite. All setae smooth. Macrosetae on Abd. V 0.9-1 times median length of tergite and 1.8-2.4 times as long as inner edge of Claw III (Table 1). Sensory chaetotaxy constituted by $m s$-setae, accp-, al- and as-setae. Only Th. II and Abd. III have $m s$-setae (formula 10/001). Dorsal $s$-setae constituted by single al-seta on Th. II and Th. III, single as-seta on Abd. V and by accp-setae (4-7 on each tergite from Th. II to Abd. V) normally set within $p$-row (Fig. 2B). The number of accp-setae can be expressed as 5-6,6/5-6,5,7,6-7,4 (Fig. 2B). The number of ordinary setae between accp-setae may vary by 1 (rarely 2) with respect to the scheme presented in Figure 2B (after Potapov 1989).

HeAD. Antennae longer than cephalic diagonal ( $\mathrm{D} / \mathrm{A}=0.79)$. Ratio among Ant. I/Ant. II/Ant. III/Ant. IV is $1 / 1.75 / 1.57 / 2.57$. Some $s$-setae well differentiated, others thick and hardly differing from ordinary setae (hereafter 'seta-like $s$-setae'). There are often cases of asymmetry among $s$-setae between antennae of the same specimen. Ant. I has about 54 setae, 6-11 short, thick and cylindrical $s$-setae and 4 seta-like $s$-setae in ventro-lateral position; 2-3 microsetae in ventro-proximal position (Fig. 2E). Ant. II has about 90 setae, $4 s$-setae and 2-3 seta-like $s$-setae (Fig. 2E). Ant. III has about 84 setae and a sensory field that includes $2 s$-setae of AO III, about $8 s$-setae and 6 seta-like $s$-setae (Figs 2E; 5C). Ant. IV plurichaetotic with more than 300 setae, with few $s$-setae and several seta-like $s$-setae; one simple small subapical, rod-shaped organite and a clearly bifurcate pin-like seta (Fig. 2D). Eye spots strongly dark pigmented with $8+8$ ocelli ( $\mathrm{G}$ and $\mathrm{H}$ usually hardly visible; Figs $2 \mathrm{C}, 5 \mathrm{~A}$ ). PAO elongated, with a weak median constriction, about 2 times as long as diameter of nearest ocellus (Fig. 2C). Prelabral setae 4. Labral formula as 5, 5, 4 and 4 sharp papillae (Fig. 4C). Maxillary palp bifurcate and maxillary outer lobe with 4 sublobal hairs (Fig. 4F). Labial palp with 5 papillae and a total of 16 guard setae (Fjellberg 1999) distributed as: $A_{1}, B_{1-4}, C_{0}, D_{1-4}, E_{1-7}$ (Fig. 4B). Hypostomal papilla with $\mathrm{H}$ as long as $h_{1} / h_{2}$. Proximal (px), basomedian (bm) and basolateral (bl) fields of labium with 4, 4 and 5 setae, respectively (Fig. 4A).

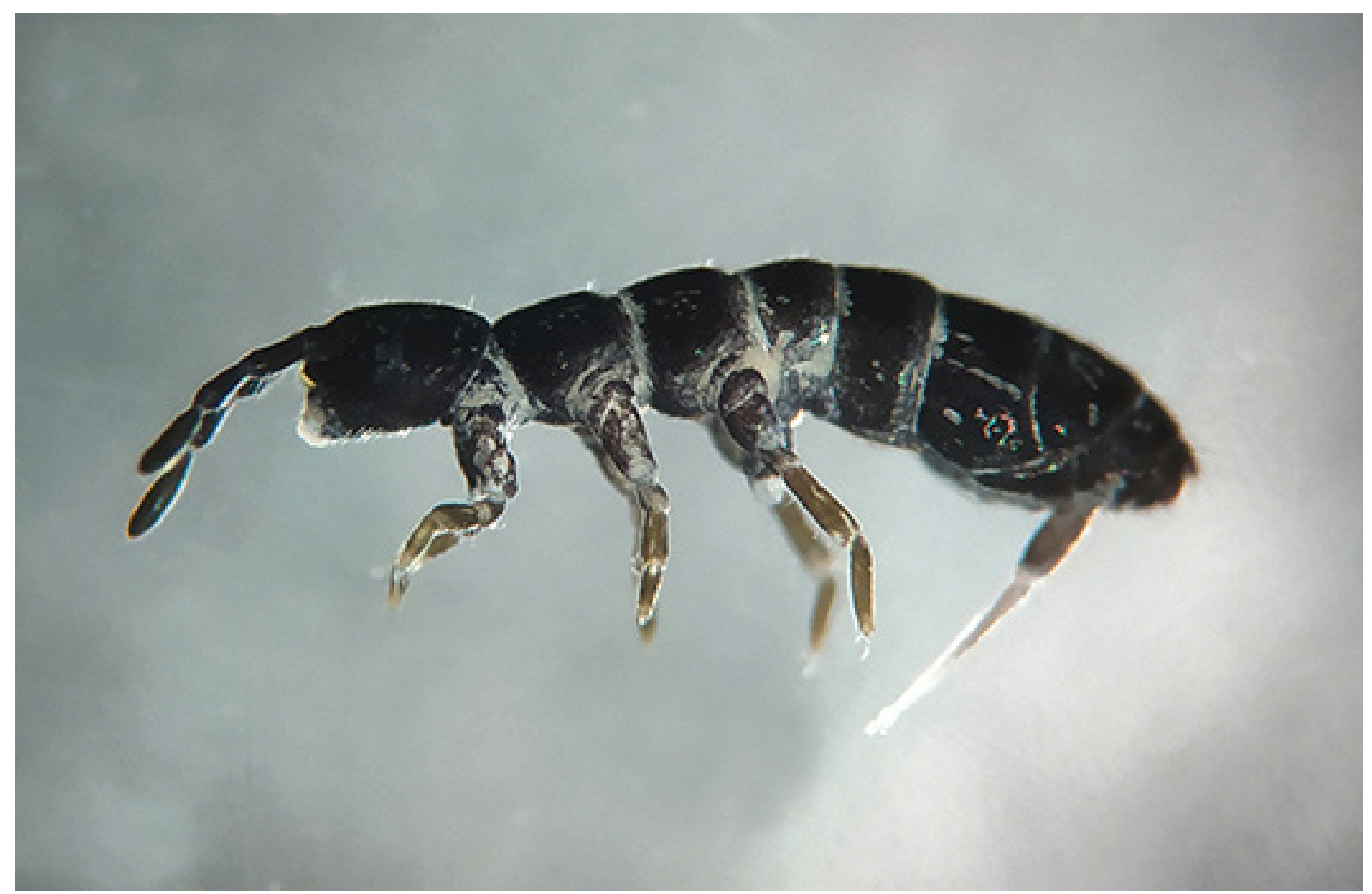

Fig. 1. Desoria calderonis sp. nov., general aspect. 


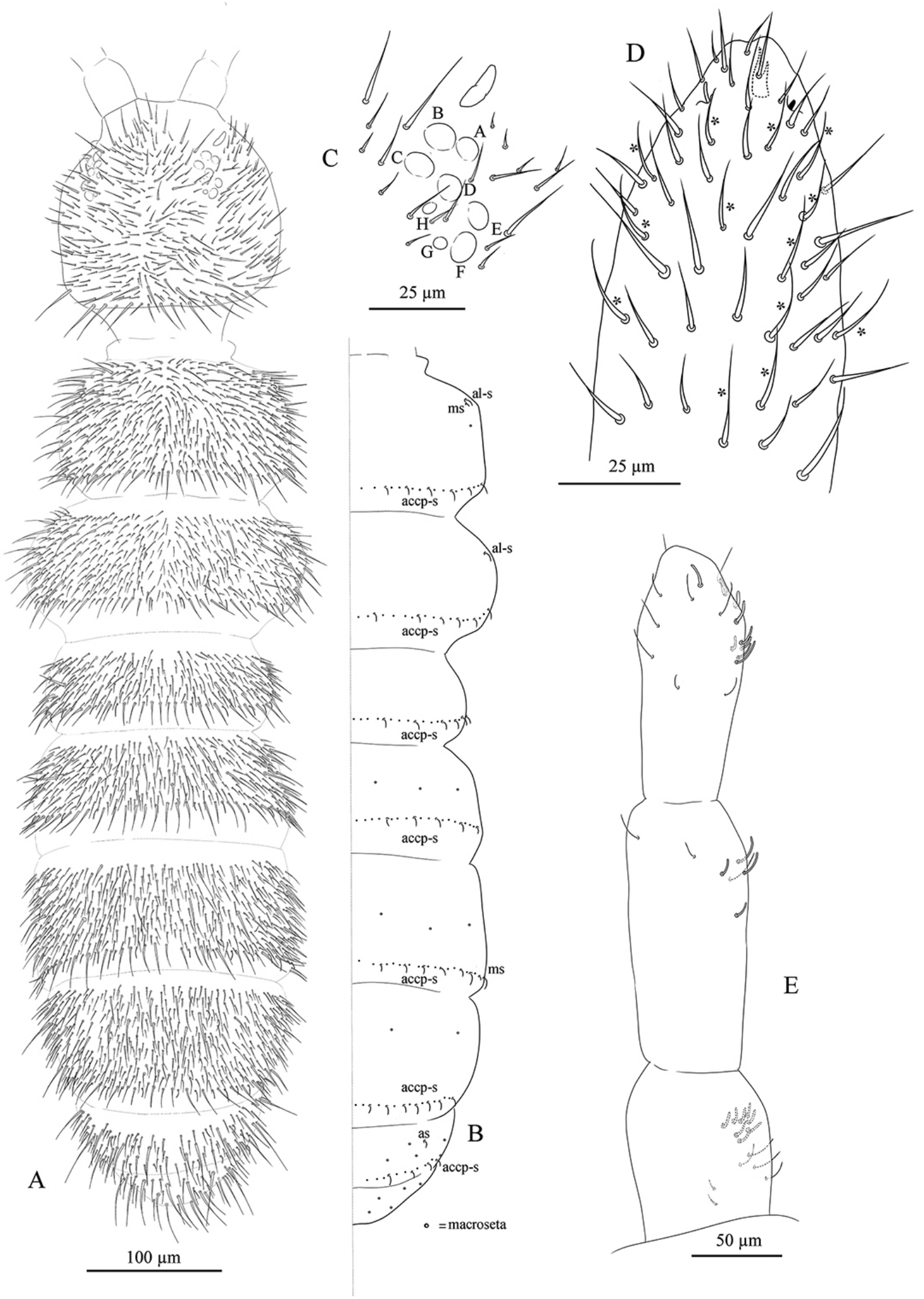

Fig. 2. Desoria calderonis sp. nov. A. Dorsal chaetotaxy. B. Number and distribution of dorsal $s$-setae (accp-s: $a c c p$-setae; al-s: $a l$-setae; as: $a s$-setae) and $m s$-setae (ms). C. Ocular plate (A-H: eyes) and PAO. D. Ant. IV apical dorsal part; asterisk = seta-like $s$-seta. E. Ant. I-III, dorsal view, with $s$-setae (double line) and seta-like $s$-setae (simple line); on ventro-proximal part of Ant. I, two isolated microsetae present. 
VALLE B. et al., A new species of cryophilic springtail (Collembola) from Italy

Table 1. Body measurements of Desoria calderonis sp. nov.

\begin{tabular}{|c|c|c|c|c|c|c|c|c|c|c|c|}
\hline & \multicolumn{11}{|c|}{ Length $(\mu \mathrm{m})$} \\
\hline & $\begin{array}{l}\text { Head } \\
\text { (dorsal) }\end{array}$ & Body & Ant. I & Ant. II & Ant. III & Ant. IV & $\begin{array}{l}\text { Cephalic } \\
\text { diagonal }\end{array}$ & Furca & $\begin{array}{c}\text { Mac } \\
\text { (Abd. V) }\end{array}$ & Abd. V & $\begin{array}{c}\text { Inner } \\
\text { edge of } \\
\text { Claw3 }\end{array}$ \\
\hline $\begin{array}{l}\text { Mean value } \\
(\mu \mathrm{m})\end{array}$ & 311 & 1171 & 61 & 107 & 97 & 164 & 338 & 495 & 191 & 193 & 95 \\
\hline $\begin{array}{l}\text { Standard } \\
\text { deviation }\end{array}$ & 20 & 82 & 8 & 11 & 12 & 15 & 39 & 43 & 10 & 13 & 8 \\
\hline $\begin{array}{l}\text { Number of } \\
\text { measurements }\end{array}$ & 11 & 12 & 12 & 12 & 12 & 12 & 5 & 12 & 11 & 10 & 11 \\
\hline
\end{tabular}

Maxilla of normal shape as in Fig. 4E, with lamellae shorter than capitulum. Ventral line of head with $9+9$ postlabial setae (Fig. 4A). Mandible with well-developed molar plate as in Fig. 4D. VT with 2-4 + 2-4 anterior, $4+4$ latero-distal and 4 posterior setae with 2 in apical transverse row (Fig. 4I). Retinaculum with 4 teeth and 7-8 setae (Figs 3F, 5D).

FurCA. Well-developed; ratio of mucro/dens/manubrium $=1 / 41 / 19$ (Fig. 3D-E). Ventral setae on manubrium numerous (about 88) and ventro-apical setae (10-12) larger than the others (Fig. 3D), with the exception of $2+2$ short apical setae; more than 70 dorsal setae (Fig. 3E). Dens with dorsal crenulations, about 200 ventral and 18 dorsal setae (Fig. 3D-E). Mucro quadridentate with apical tooth much smaller than subapical one (Fig. 3G).

LEgS. Upper and lower subcoxa of Leg I with 1 outer seta (Fig. 3A). Upper subcoxa of Leg II with 7, lower subcoxa with 6 outer setae (Fig. 3B). Upper subcoxa of Leg III with 10, lower subcoxa with 19 outer setae (Fig. 3C). Coxa with 5, 10, 24 setae, respectively, on leg I, II, III (Fig. 3A-C). Trochanter with 20, 21, 20 setae, respectively, on leg I, II, III. Femur with 36, 42, 74, respectively, on leg I, II, III. Tita with 45, 54,96 setae, respectively, on Leg I, II, III; tenent hair pointed (Fig. 3I). Claw of normal shape with lateral and inner teeth; empodium with a small inner tooth; pretarsus with a pair of setae (Fig. 3I).

\section{Measurements}

See Table 1.

\section{Ecology}

Desoria calderonis sp. nov. was found only on supraglacial stony debris of the Calderone glacier at 2650-2700 m a.s.l. (Appendix 1A). The supraglacial stony debris (carbonate: dolomite and limestone) is very coarse and the fine component is poorly represented (Appendix 1B). In this mineral, inorganic soil, D. calderonis sp. nov. was found mostly where the debris is in contact with the ice (Appendix 1B). In this environment, the vegetation cover is almost absent, with the rare exception of sporadic seedlings of Arabis alpina ssp. caucasica (Willd.) Briq. On supraglacial debris the mean annual temperature is $0.67^{\circ} \mathrm{C}\left(4.6^{\circ} \mathrm{C}\right.$ during the snow-free period), the minimum recorded was $-7.7^{\circ} \mathrm{C}$ and maximum $36.1^{\circ} \mathrm{C}$; the snow cover persists on average for 250 days a year; the relative humidity is on average $95.7 \%$ during the whole year $(85.9 \%$ during the snow-free period). Since $D$. calderonis sp. nov. was found only on supraglacial stony debris, and not in the surrounding habitats (LIA moraines: mean annual temperature $=$ $1.3^{\circ} \mathrm{C}$, mean temperature during snow-free period $=4.4^{\circ} \mathrm{C}$; minimum $=-9.8^{\circ} \mathrm{C}$; maximum $=40.7^{\circ} \mathrm{C}$; annual relative humidity $=88.7 \%$; mean relative humidity during the snow-free period $=84.7^{\circ} \mathrm{C}$; snow cover duration $=146$ days), we can consider this species as cryophilic. On supraglacial debris, $\mathrm{pH}$ is 8.6, the organic matter content is $1.7 \mathrm{~g} / \mathrm{kg}$ and carbonate calcium content is $96.2 \%$, while on LIA moraine, $\mathrm{pH}$ is 8.3 , organic matter content is $3.9 \mathrm{~g} / \mathrm{kg}$ and carbonate calcium content is $91.4 \%$. 

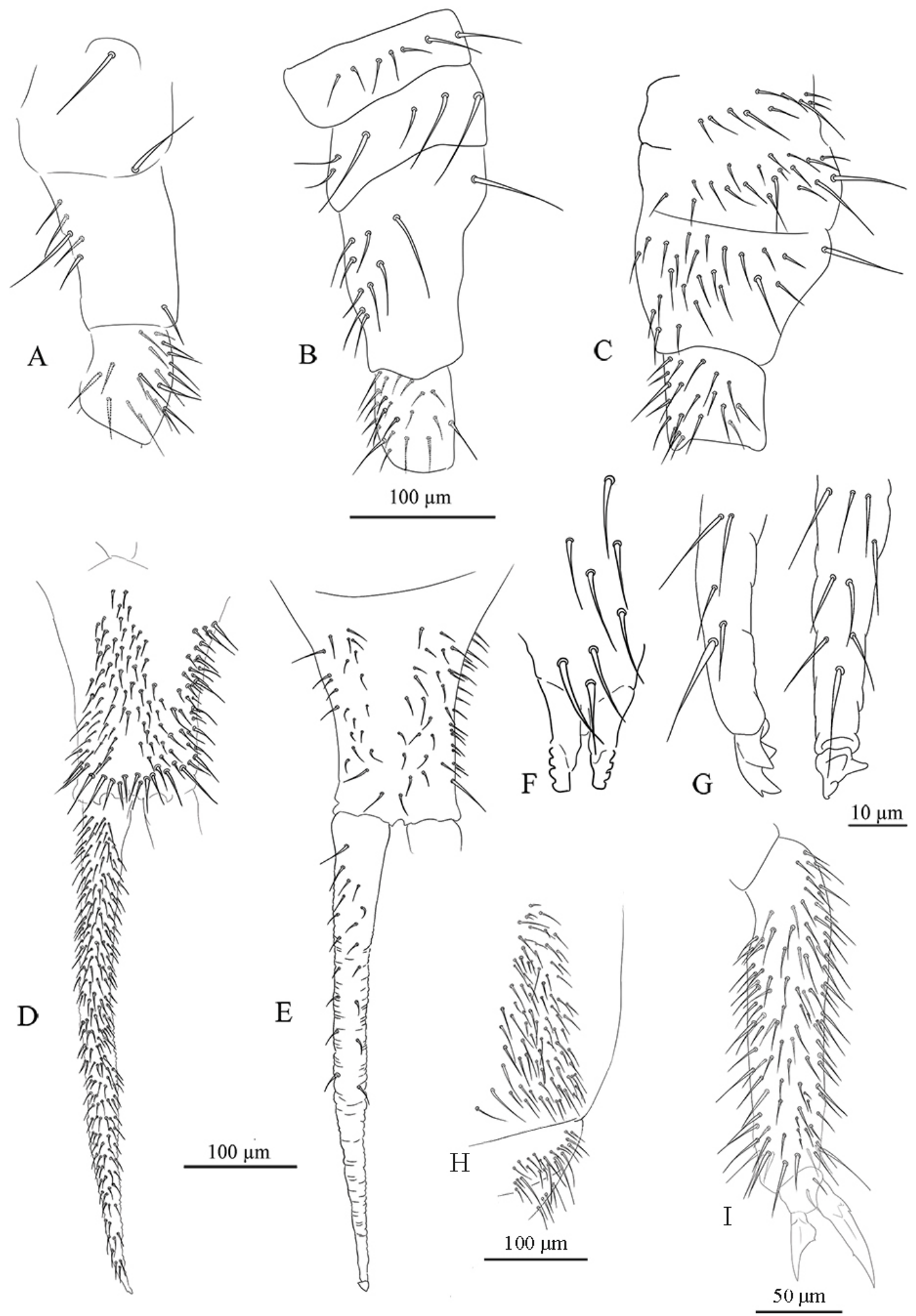

Fig. 3. Desoria calderonis sp. nov. A. Leg I, left; upper and lower subcoxa, coxa and trochanter. B. Leg II, left; upper and lower subcoxa, coxa and trochanter. C. Leg III, left; upper and lower subcoxa, coxa and trochanter. D. Ventral side of furca. E. Dorsal side of furca. F. Retinaculum. G. Mucro and apical part of dens, lateral and dorsal views. H. Lateral part of Abd. IV-V sternites. I. Tita III and Claw III. 
Table 2 (continued on next page). Characters important for Desoria taxonomy are compared for the species of the violacea-group. The green colour highlights characteristics common between $D$. calderonis sp. nov. and all other known species of the group (with an inclusive criterion, in order not to overestimate differences, but, at least, to underestimate them).

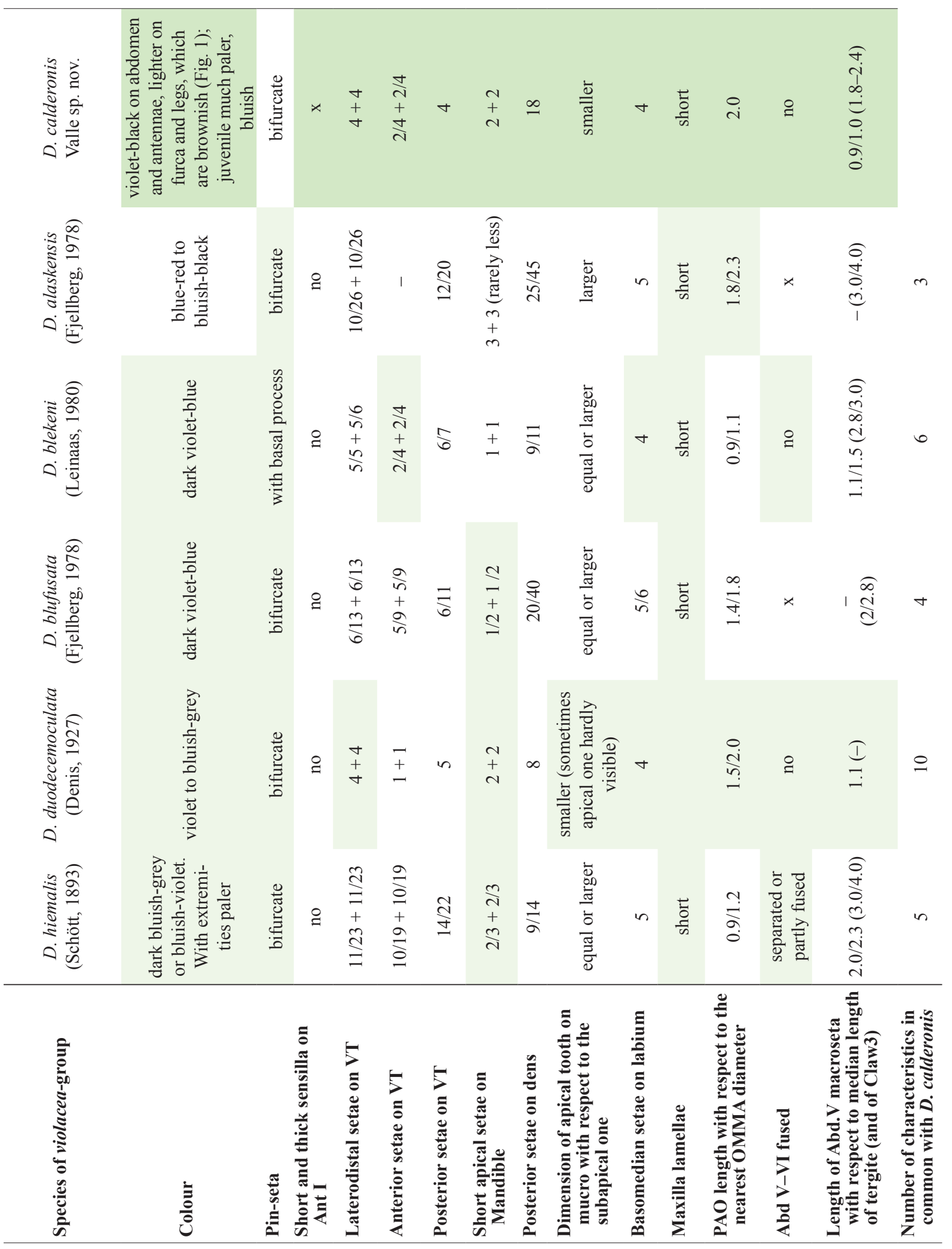


Table 2 (continued).

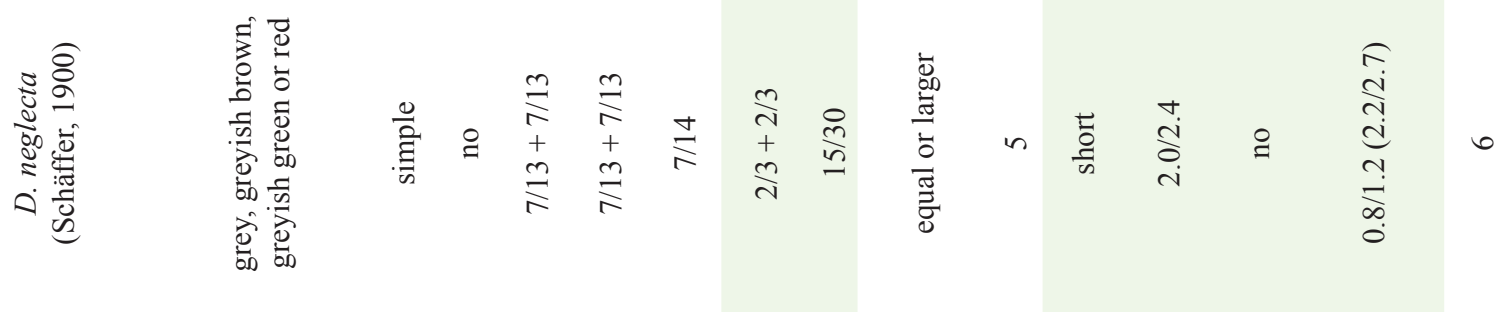

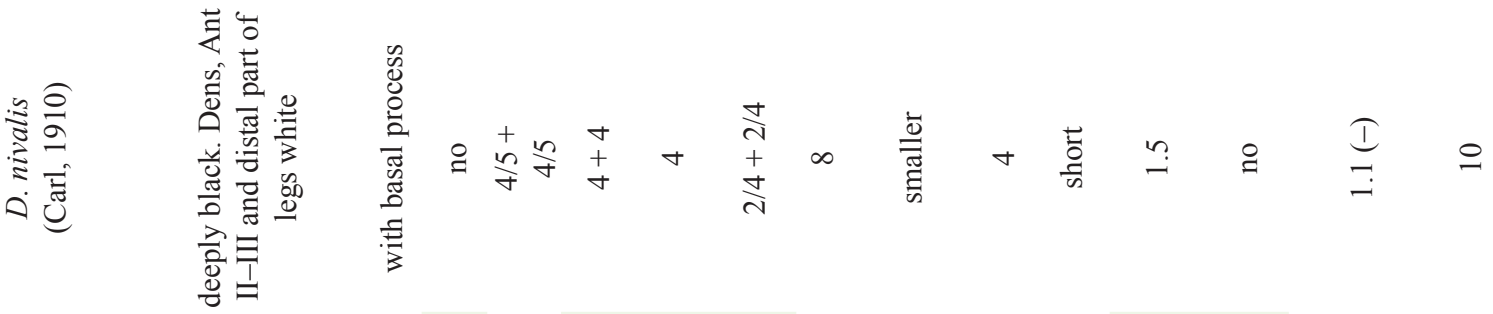

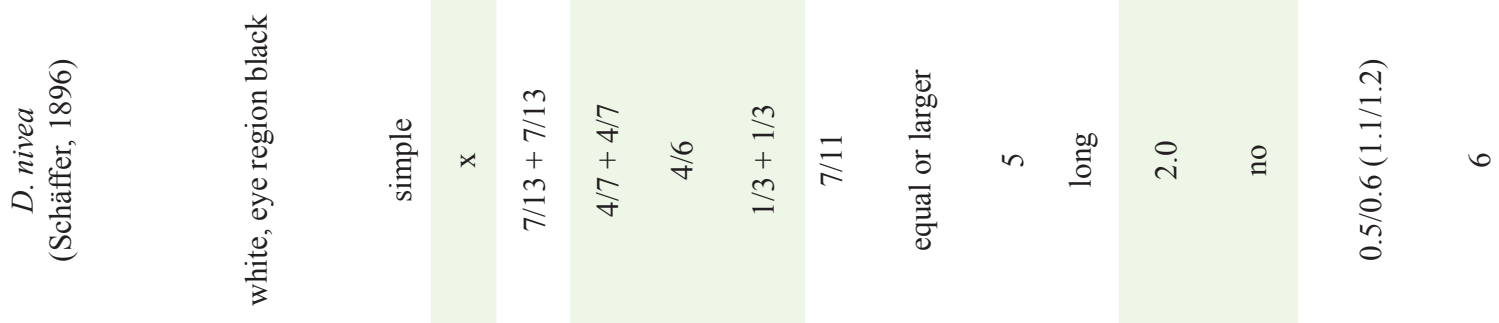

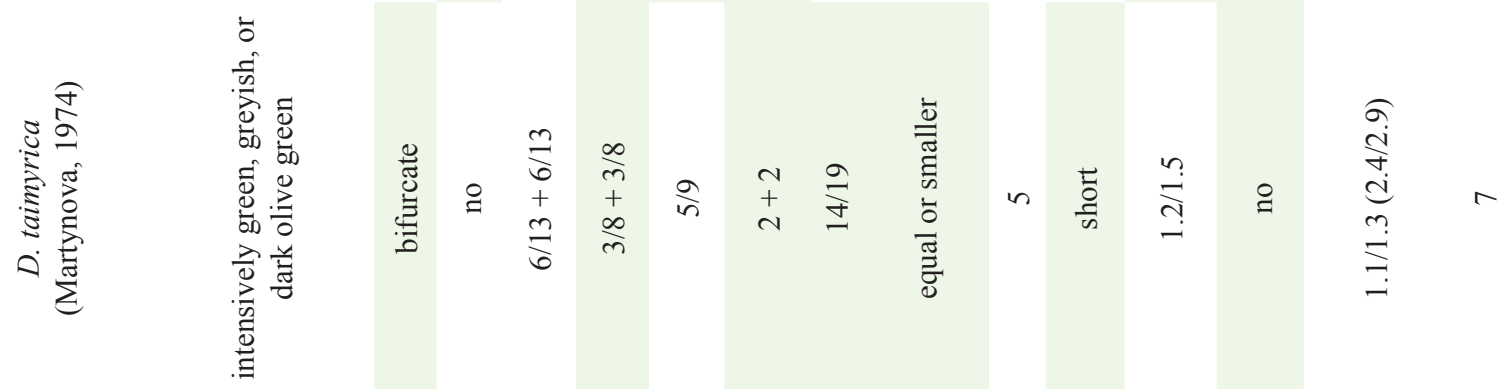

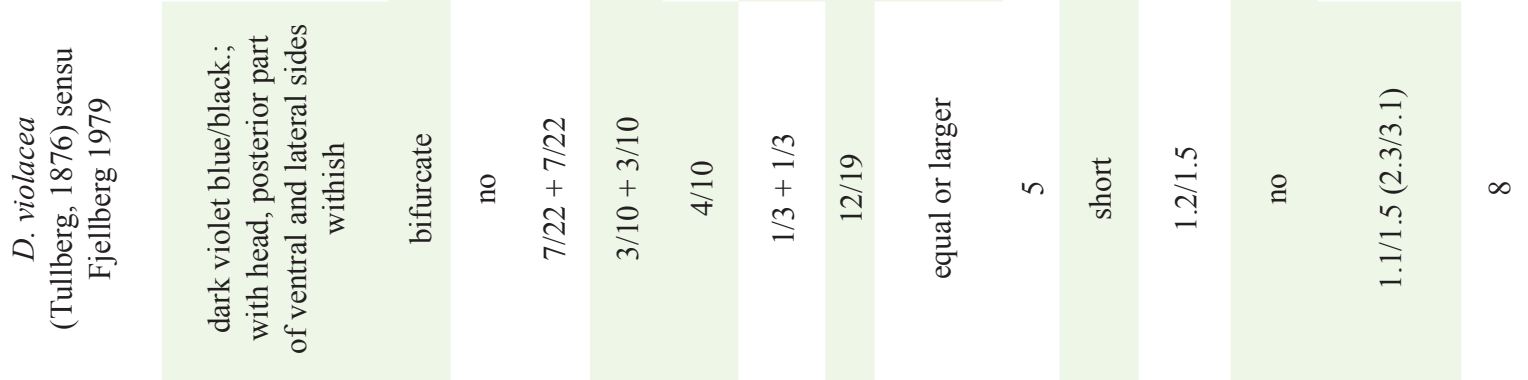

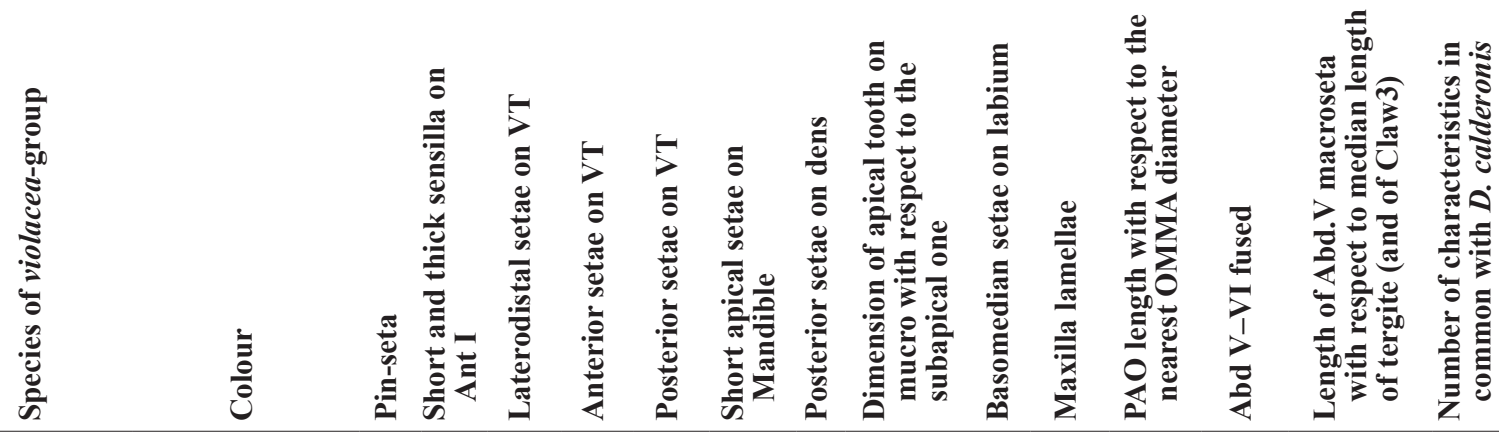


VALLE B. et al., A new species of cryophilic springtail (Collembola) from Italy

\section{Distribution}

Desoria calderonis sp. nov. is currently known only for the type locality.

\section{Type locality}

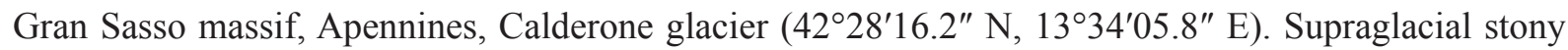
debris of Calderone glacier, altitude: $2650-2700 \mathrm{~m}$ a.s.l.

\section{Taxonomic and ecological considerations}

Desoria calderonis sp. nov. belongs to the violacea-group sensu Potapov 2001, having mucro quadridentate, without seta, maxillary palp bifurcate, apical folds on labrum sharp. It differs from most species of this group (Table 2) by the reduced number of setae on VT (with the exception of D. duodecemoculata (Denis, 1927) and D. nivalis (Carl, 1910), which also have few setae, but in a different number). Desoria calderonis sp. nov., in addition, has a characteristic sensory field on Ant I with short, thick and cylindrical s-setae; this characteristic is common, for Palearctic Desoria, to many species of the fennica-group (sensu Potapov 2001) - D.atkasukiensis (Fjellberg, 1978), D. fennica (Reuter, 1895) sensu Fjellberg 1979, D. fjellbergi (Najt, 1981), D. iuxta (Dunger, 1982), D. kaszabi (Dunger, 1982), D. saltans, D. tigrina Nicolet, 1842 - two species of olivacea-group - D. infuscata (Murphy, 1959) and D. olivacea (Tullberg, 1871) sensu Fjellberg 1979 - and only one species of the violacea-group $-D$. nivea (Schäffer, 1896). Among species of the violacea-group, another peculiarity of $D$. calderonis sp. nov. is the number of dorsal setae on the dens, similar only to that in $D$. neglecta (Schäffer, 1900) sensu Fjellberg 1978, D. taimyrica (Martynova, 1974) and D. violacea (Tullberg, 1876) sensu Fjellberg 1979. In general, D. calderonis sp. nov. differs by a combination of at least four important characters (Table 2 ) from every species of the group.

Within the group, considering the number of common characteristics, D. calderonis sp. nov. appears most similar to D. duodecemoculata - present in Italy, Austria, Spain and France (Potapov 2001) - and D. nivalis, present in the Alps (France, Switzerland, Austria) and possibly in eastern Europe (Potapov 2001) (Table 2). Nevertheless, some features allow us to discriminate the new species from these. First, $D$. duodecemoculata and $D$. nivalis do not have short, thick and cylindrical, but only hairlike $s$-setae on Ant I. In addition, the new species differs from $D$. duodecemoculata by the chaetotaxy of VT and the number of dorsal setae on the dens; it differs from $D$. nivalis by having Ant II-III violet-black (white in D. nivalis), a longer PAO and by the number of dorsal setae on the dens.

Both $D$. duodecemoculata and D. nivalis belong to the nivalis-complex, a group of European mountain species included in the violacea-group. Desoria nivalis, in particular, is known to live near snow fields and other cold sites in high mountains (Handschin 1924; Franz \& Serrl-Butschek 1954), while the ecology and the taxonomy of the other members of the complex need to be revised (Potapov 2001). Because of these similarities in morphology and ecology, we could ascribe our species to this nivaliscomplex, even if we reported marked differences, in particular the presence in D. calderonis sp. nov. of the sensory field on Ant. I.

\section{Phylogenetic context}

The phylogenetic tree (Fig. 6), with a log-likelihood of 3077.45, is characterized by good support at recent nodes but low support at deeper nodes. It appears subdivided into three major clusters, two dominated by Isotoma and Isotomurus, respectively, and one by Desoria, with records representing 14 different Desoria species as well as others incompletely identified as Desoria sp. This latter cluster also included scattered sequences from the following genera: Vertagopus, Pseudisotoma, Isotoma, Skadisotoma, Proisotoma, Isotomurus, Agrenia, Metisotoma, Axelsonia, Chionobora and Kaylathalia. Within the Desoria cluster, Desoria calderonis sp. nov. clustered with high support (99) with one bin 


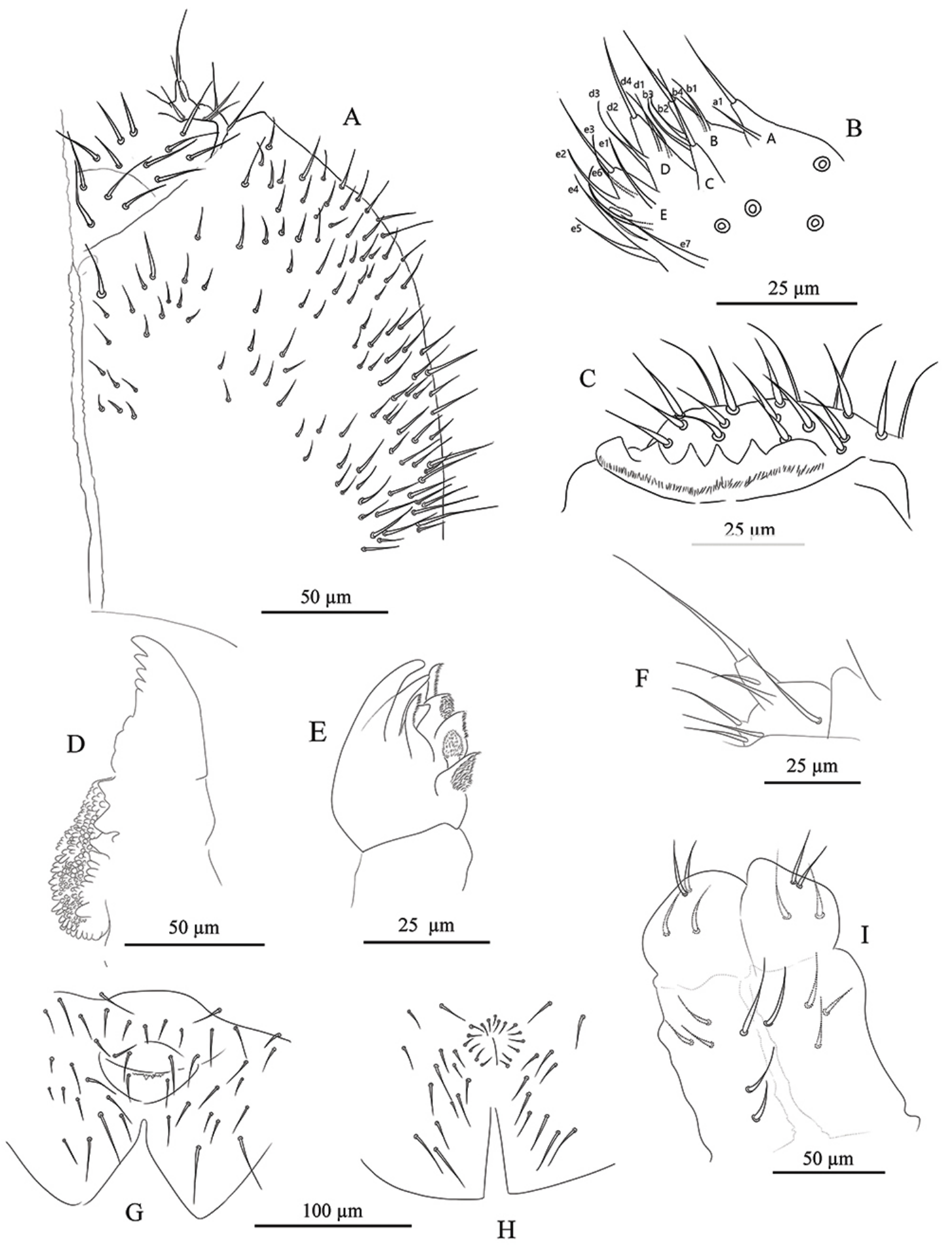

Fig. 4. Desoria calderonis sp. nov. A. Ventral chaetotaxy of head. B. Labial palps. C. Labrum. D. Mandible. E. Maxilla. F. Maxillary palp. G. Female genital opening. H. Male genital opening. I. VT in posterior view. 
VALLE B. et al., A new species of cryophilic springtail (Collembola) from Italy

(AAO3603) identified as Desoria (with no indication on the species, 4 sequences from France) and Vertagopus arboreus (1 sequence from Ontario, Canada). The mean divergence between $D$. calderonis sp. nov. and this bin is $16.9 \%$ (S.D. 0.2). Both bins were associated (support 97) with one record of D. tigrina and this latter cluster, although with lower support, was associated with records of D. blufusata, $D$. germanica, $D$. intermedia and $D$. violacea.
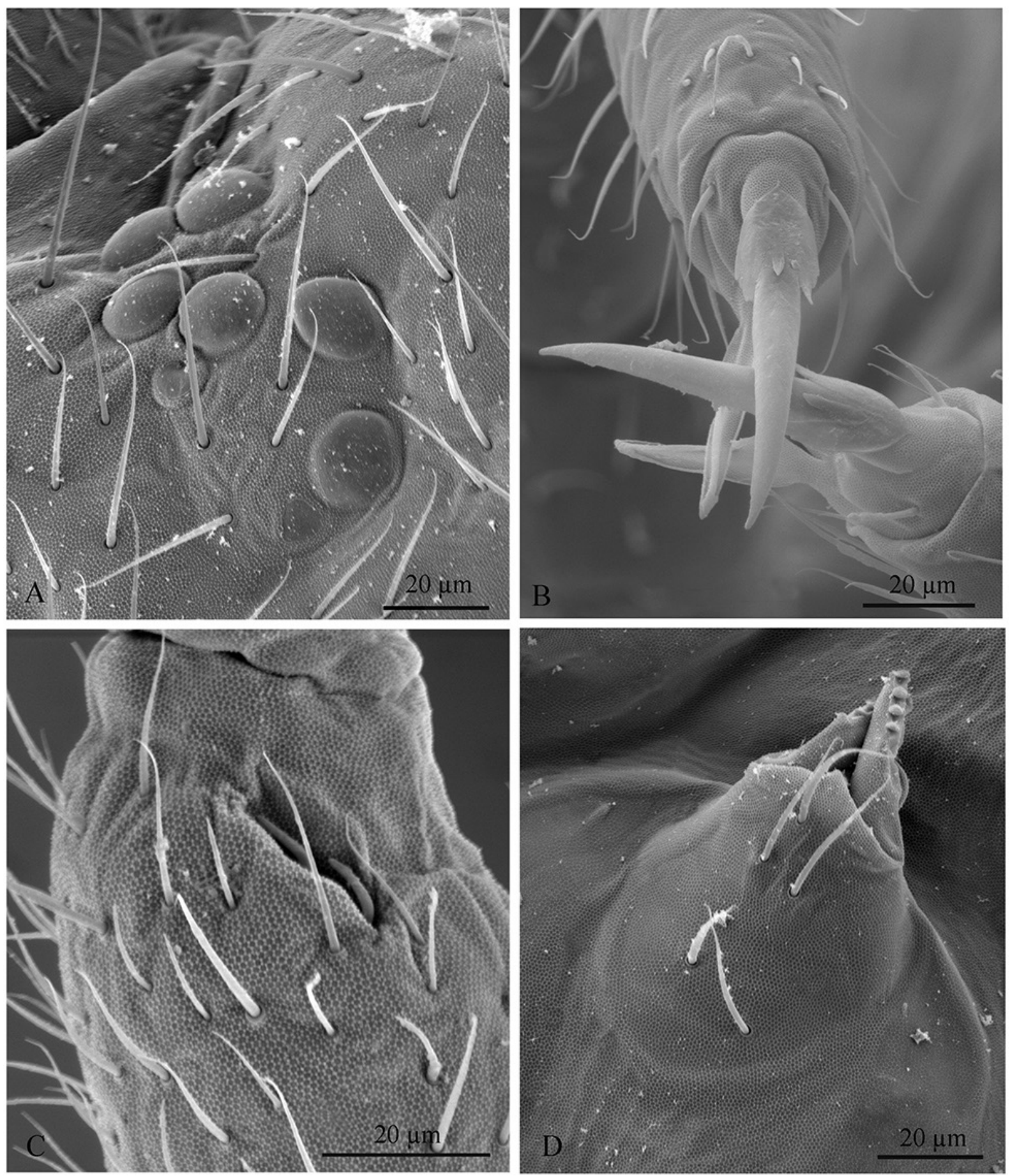

Fig. 5. Desoria calderonis sp. nov., scanning electron microscopy. A. Ocular plate. B. Claws. C. Antennal organ III. D. Retinaculum. 
Apart from D. violacea (BOLD:AEA8472), D. tigrina (BOLD:ACS3918), Vertagopus arboreus (BOLD:AAO3603), and individual records mined from GenBank with no location information, all others reports come from areas characterized by a markedly cold climate, mostly in Northern Europe. Similarly to D. calderonis sp. nov., D. blufusata (BOLD:ACT9239, 3 records), D. intermedia (BOLD:AAI9461, 4 records) and D. germanica (BOLD:AAI9461, 2 records; see Stevens et al. 2006 for sampling information) were collected in low-temperature habitats, specifically in Norway and Sweden, with two records of $D$. intermedia explicitly associated to a snow covered setting. At variance, Desoria sp. (BOLD:AAO3603), for which species level identification is missing, originated from British Columbia (Canada) as well and the Ile-de-France (France).

\section{Discussion}

Our analysis supports the idea that Desoria is a polyphyletic group, as already observed by Stevens \& D'Haese (2017). In particular, Desoria clustered with Vertagopus, Pseudisotoma, Isotoma, Skadisotoma, Proisotoma, Isotomurus, Agrenia, Metisotoma, Axelsonia, Chionobora and Kaylathalia. Most of the Desoria records came from areas characterized by a markedly cold climate and here cluster with other strictly cold-adapted and cryophilic organisms. In particular, Agrenia Börner, 1906 is a Holarctic genus living in damp and cold habitats such as banks of cold-water streams and the shores of lakes in tundra and mountain zones (Fjellberg 1988), on or near snow (Fjellberg 1976, 1986, 1994) and polar deserts (Chernov et al. 1977). Hågvar (2010) reported A. bidenticulata, Desoria olivacea and D. infuscata as the most pioneer species of the proglacial succession along Midtdalsbreen glacier (Norway). Skadisotoma Greenslade \& Fjellberg, 2015 is a mountain endemic Australian genus linked to snow patches (Greenslade \& Fjellberg 2015) and taxonomically related to Desoria. Chionobora Greenslade \& Potapov, 2015 is an endemic hygrophilous Tasmanian genus, living around the lakes of the Central Plateau, the largest area of high ground in Tasmania. Kaylathalia is an Antarctic isotomid and was regarded as belonging to Desoria until Stevens \& D'Haese (2017). Isotoma and Isotomurus are present in this cluster with a few sparse sequences identified at the genus level, but most of the sequences belonging to these genera were grouped in two alternative well defined groups outside the Desoria cluster. Thus, we hypothesize that the sparse Isotoma and Isotomurus sequences clustering with Desoria could be phylogenetically misplaced or not properly identified specimens. Therefore, we suppose that the genera more strictly related to Desoria are Vertagopus, Skadisotoma, Agrenia, Metisotoma, Axelsonia, Chionobora and Kaylathalia.

The position of the new species in a cluster composed entirely of Desoria sequences (with the exception of a single sequence of Vertagopus) supports its morphological identification as belonging to the genus. Desoria calderonis sp. nov. is dissimilar (17.8\% genetic variability) to all other sequences present in the BOLD database. Morphologically, D. calderonis sp. nov. is more similar to D. nivalis and D. duodecemoculata of the mountain and cold-adapted nivalis-complex (violacea-group). However, this affinity was not testable phylogenetically with the available dataset, since no sequences from this complex are present.

In terms of subgeneric relationships, $D$. calderonis sp. nov. appears to be related to species belonging to both the fennica- (D. tigrina: bin BOLD:ACS3918; D. germanica and D. intermedia: bin BOLD:AAI9461) and violacea-group (D. blufusata: bin BOLD:ACT9239 and D. violacea: BOLD:AEA8472), leaving the question of its morphological assignment to the violacea-group untestable. In general, our phylogenetic results do not support the morphological groups reported by Potapov (2001) as natural assemblages.

From a methodological standpoint, the Desoria phylogeny presented here is difficult to interpret due to the possibility that some key groups are polyphyletic, the lack of sequence data for crucial elements and the uncertainty in the attribution of some sequences. In fact, building robust phylogenetic trees would require the combination of data from a large number of genes, integrating nuclear and mitochondrial 


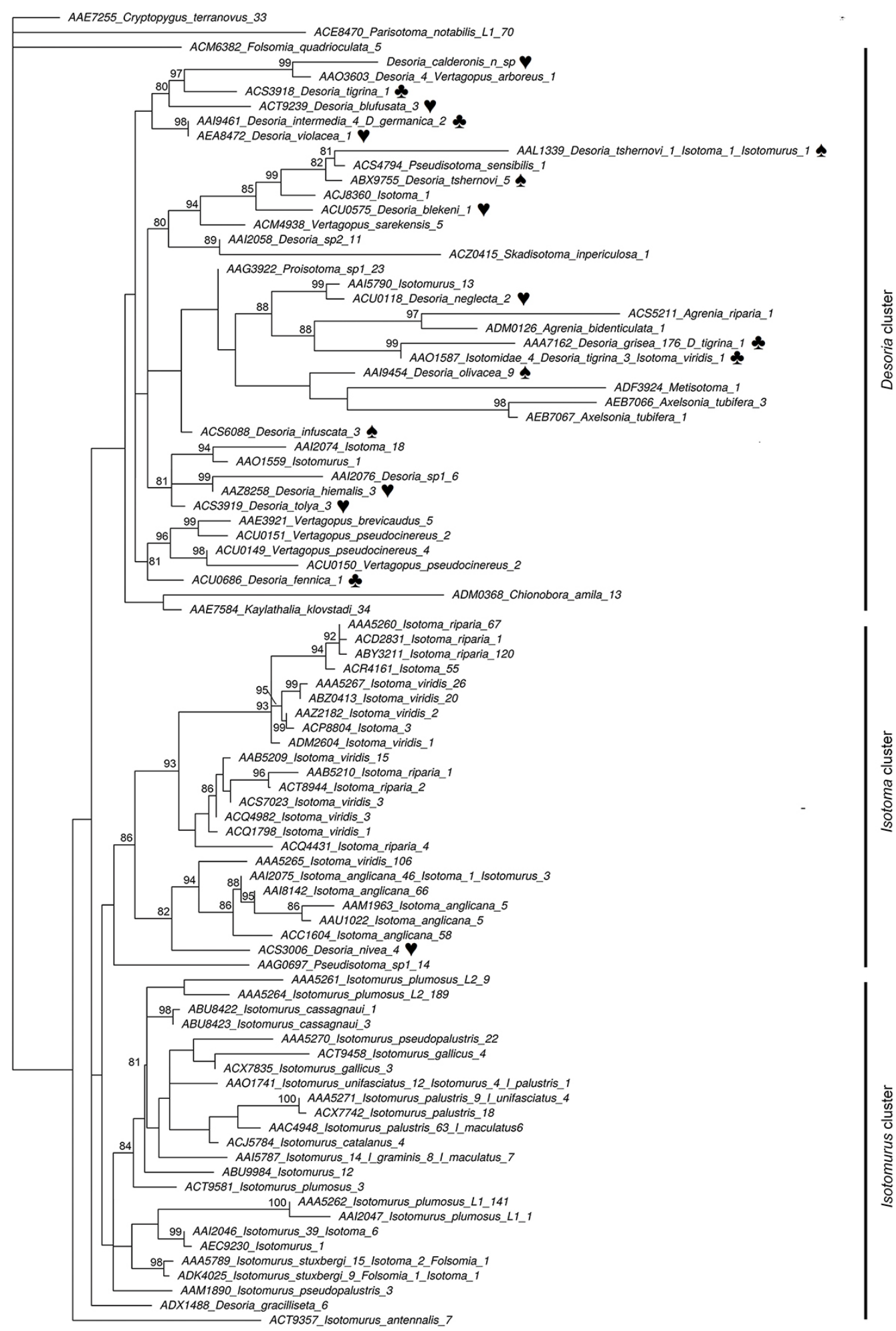

Fig. 6. Phylogenetic tree of Desoria calderonis sp. nov. and related species, on the basis of the cox 1 gene. Names include the BOLD bin number, as well as the taxonomic attribution and number of sequences included in the bin. Genera were abbreviated where unambiguous within the bin. When records of the same bin had multiple taxonomic attributions, the one at the lowest level was retained if all were compatible. Alternatively, all were listed separately. Bootstrap support is indicated if $>80$. olivaceagroup; fennica-group; $\mathbf{v}$ : violacea-group of Desoria. 
information, and the coxl barcoding fragment is suboptimal in terms of resolution, especially at deeper nodes. Nevertheless, a great advantage of coxl is the availability of a large number of sequences in the BOLD database, including sequences from rare or difficult to sample species. Thus, the use of this gene allows for preliminary considerations on the phylogenetic context of the new species even in the absence of a consolidated taxonomy of the group, which would require more complete phylogenetic analyses.

Desoria species, with few exceptions (e.g., D. violacea, xerophilic, D. blekeni, mesophilic; Fjellberg 1975, 1988; Leinaas 1980), are cold and wet adapted organisms (Potapov 2001). Cold and wet environments are more common in northern Europe also in mountain forests, ponds and rivers. In Mediterranean regions, these environments are extremely fragmented and there is evidence that cryophilic springtails could find suitable habitat - ice - only in isolated refugial areas, like caves (Raschmanová et al. 2018) or alpine glaciers, glacierets, the banks of glacial streams and permanent snowfields (Lauga-Reyrel \& Lauga 1995; Fjellberg 2010). This fragmentation of suitable habitats is compatible with the notion of a great undescribed cryophilic endemic biodiversity, largely constituted by springtails taxonomically related to the Desoria genus (Deharveng 1975; Najt 1981; Lauga-Reyrel \& Lauga 1995; Fjellberg 2010; Hittorf 2017).

Desoria calderonis sp. nov. was described for the Calderone glacier, a relict, isolated glacier of the Apennines, a peripheral mountain chain without other existing glaciers. This is in line with the hypothesis of an undescribed fragmented glacial springtail biodiversity in refugial areas. It is noteworth that, these glacial areas are highly threatened by climate change (Grunewald \& Scheithauer 2010). We do not know the fate of the cold adapted and cryophilic collembolan fauna in these areas, but extinction seems to be a likely scenario (Greenslade \& Fjellberg 2015). This underlines the importance of studying these unique environments and preserving their biodiversity in order to know it before its definitive disappearance.

\section{Acknowledgments}

The authors thank L'ubomír Kováč and the anonymous reviewer who provided helpful comments that improved the manuscript, and Georgine Faulkner and Giorgio Valle for the linguistic revision. We also wish to thank the staff of the Rifugio Franchetti that gave us an important logistic support during the field work. B.V. also thanks her dad for having inspired the work. This work was partially funded by the European Research Council under the European Community's Horizon 2020 Programme, Grant Agreement no. 772284 (IceCommunities) (G.F. Ficetola).

\section{References}

Bellinger P.F., Christiansen K.A. \& Janssens F. 1996-2021. Checklist of the Collembola of the World. Available from http://www.collembola.org [accessed 6 Dec. 2021].

Buda J., Azzoni R.S., Ambrosini R., Franzetti A. \& Zawierucha K. 2020. Effects of locality and stone surface structure on the distribution of Collembola inhabiting a novel habitat - the stone-ice border on an alpine glacier. Acta Oecologica 108: e103629. https://doi.org/10.1016/j.actao.2020.103629

Carl J. 1901. Zweiter Beitrag zur Kenntnis der Collembolenfauna der Schweiz. Revue suisse de Zoologie 9: 243-278. Not quoted in the text. https://doi.org/10.5962/bhl.part.20304

Cauvy-Fraunié S. \& Dangles O. 2019. A global synthesis of biodiversity responses to glacier retreat. Nature Ecology \& Evolution 3: 1675-1685. https://doi.org/10.1038/s41559-019-1042-8

Chernov Ju. I., Striganova B.R. \& Ananjeva S.I. 1977. Soil fauna of the polar deserts at Cape Chelusik, Taimyr Peninsula, URSS. Oikos 29: 175-179. https://doi.org/10.2307/3543310

Deharveng L. 1975. Contribution à l'Étude biogéographique et écologique des Collemboles cryophile. Thèse de doctorat de $3^{\circ}$ cycle. Université Paul Sabatier, Toulouse, France. 
VALLE B. et al., A new species of cryophilic springtail (Collembola) from Italy

Deharveng L., D’Haese C.A. \& Bedos A. 2008. Global diversity of springtails (Collembola; Hexapoda) in freshwater. Hydrobiologia 595: 329-338. https://doi.org/10.1007/s10750-007-9116-z

Fjellberg A. 1975. Organization and dynamics of Collembola populations on Hardangervidda. Fennoscandian Tundra Ecosystems 17: 73-79.

Fjellberg A. 1976. Collembola from mountains in South Norway. Norwegian Journal of Entomology 23: $127-137$.

Fjellberg A. 1986. Revision of the genus Agrenia Börner, 1906 (Collembola, Isotomidae). Entomologica Scandinavica 17: 93-106.

Fjellberg A. 1988. The Collembole fauna of Troms and Finmark, North Norway (Collembola). Fauna Norvegica B 35: 5-20.

Fjellberg A. 1994. The Collembola of the Norwegian Arctic Islands. Meddelelser no. 133. Norsk Polarinstitutt, Tromsø, Norway.

Fjellberg A. 1999. The labial palp in Collembola. Zoologischer Anzeiger 237: 309-330.

Fjellberg A. 2007. The Collembola of Fennoscandia and Denmark. Part II: Entomobryomorpha and Symphypleona. Fauna Entomologica Scandinavica. Brill, Leiden, Boston.

Fjellberg A. 2010. Cryophilic Isotomidae (Collembola) of the Northwestern Rocky Mountains, U.S.A. Zootaxa 2513 (1): 27-49. https://doi.org/10.11646/zootaxa.2513.1.2

Folmer O., Black M., Hoeh W., Lutz R. \& Vrijenhoek R. 1994. DNA primers for amplification of mitochondrial cytochrome c oxidase subunit I from diverse metazoan invertebrates. Molecular Marine Biology and Biotechnology 3 (5): 294-299.

Franz H. \& Serrl-Butschek E. 1954. Ordnung Collembola. In: Franz H. (ed.) Die Nordost-Alpen im Spiegel ihrer Landthierwelt 1: 79-641. Universitätsverlag Wagner, Innsbruck, Austria.

Gobbi M., Ambrosini R., Casarotto C., Diolaiuti G., Ficetola G.F., Lencioni V., Seppi R., Smiraglia C., Tampucci D., Valle B. \& Caccianiga M. 2021. Vanishing permanent glaciers: climate change is threatening a European Union habitat (Code 8340) and its poorly known biodiversity. Biodiversity and Conservation 30: 2267-2276. https://doi.org/10.1007/s10531-021-02185-9

Greenslade P. \& Fjellberg A. 2015. Skadisotoma, a new genus of Isotomidae (Collembola) from Australia. Zootaxa 3972 (4): 573-580. https://doi.org/10.11646/zootaxa.3972.4.8

Grunewald K. \& Scheithauer J. 2010. Europe's southernmost glaciers: response and adaptation to climate change. Journal of Glaciology 56 (195): 129-142. https://doi.org/10.3189/002214310791190947

Hågvar S. 2000. Navigation and behaviour of four Collembola species migrating on the snow surface. Pedobiologia 44: 221-233. https://doi.org/10.1078/S0031-4056(04)70042-6

Hågvar S. 2010. Primary succession of springtails (Collembola) in a Norwegian glacier foreland. Arctic, Antarctic, and Alpine Research 42: 422-429. https://doi.org/10.1657/1938-4246-42.4.422

Hågvar S., Gobbi M., Kaufmann R., Ingimarsdóttir M., Caccianiga M., Valle B., Pantini P., Fanciulli P.P. \& Vater A. 2020. Ecosystem birth near melting glaciers: a review on the pioneer role of grounddwelling arthropods. Insects 11: e644. https://doi.org/10.3390/insects11090644

Handschin E. 1924. Die Collembolenfauna des Schweizerischen Nationalparkes. Denkschriften der schweizerischen naturforschenden Gesellschaft 60: 89-174.

Hao C., Chen T.-W., Wu Y., Chang L. \& Wu D. 2020. Snow microhabitats provide food resources for winter-active Collembola. Soil Biology and Biochemistry 143: e107731.

https://doi.org/10.1016/j.soilbio.2020.107731 
Hittorf M. 2017. Collembola of the Glacier Foreland - Pioneers Colonizing Moraines. LeopoldFranzens-Universität, Innsbruck, Austria.

Jureková N., Raschmanová N., Miklisová D. \& Kováč L'. 2021. Mesofauna at the soil-scree interface in a deep karst environment. Diversity 13: e242. https://doi.org/10.3390/d13060242

Katoh K. 2002. MAFFT: a novel method for rapid multiple sequence alignment based on fast Fourier transform. Nucleic Acids Research 30: 3059-3066. https://doi.org/10.1093/nar/gkf436

Lauga-Reyrel F. \& Lauga J. 1995. Collembola of cold Pyrenean habitats. European Journal of Soil Biology 31: 217-229.

Leinaas H.P. 1980. Isotoma blekeni n. sp. (Collembola: Isotomidae) from coniferous forest in Norway. Ecological segregation of related, coexisting species. Revue d'Écologie et de Biologie du Sol 17: 281-289.

Makowska N.,Zawierucha K., Mokracka J. \& Koczura R. 2016. First report of microorganisms of Caucasus glaciers (Georgia). Biologia (Bratislava) 71: 620-625. https://doi.org/10.1515/biolog-2016-0086

Marshall S.A., Anderson R.S., Roughley R.E., Behan-Pelletier V. \& Danks H.V. 1994. Terrestrial Arthropod Biodiversity: Planning a Study and Recommended Sampling Techniques. A Brief Prepared by the Biological Survey of Canada (Terrestrial Arthropods). Biological Survey of Canada, Commission biologique du Canada, Ottawa, Canada.

Najt J. 1981. Contribution à l'étude de la phylogenèse et de l'écomorphose chez les Isotoma: le sous-genre Gnathisotoma (Collembole, Isotomidae) et l'espèce-souche I. (Desoria) fjellbergi n. sp. Bulletin du Muséum national d'histoire naturelle, 4e sér. 3: 415-430. Available from https://www.biodiversitylibrary.org/page/58252218. [accessed 6 Dec. 2021].

Nguyen L.-T., Schmidt H.A., von Haeseler A. \& Minh B.Q. 2015. IQ-TREE: A fast and effective stochastic algorithm for estimating Maximum-Likelihood phylogenies. Molecular Biology and Evolution 32: 268-274. https://doi.org/10.1093/molbev/msu300

Potapov M. 1989. The use of sensorial chaetotaxy of some Isotomidae (Collembola). In: Dallai R. (ed.) $3^{\text {rd }}$ International Seminar on Apterygota: 35-42. University of Siena, Siena, Italy.

Potapov M. 2001. Isotomidae. Synopses on Palaearctic Collembola. Senckenberg Museum of Natural History, Görlitz, Germany.

Raschmanová N., Miklisová D. \& Kováč L'. 2018. A unique small-scale microclimatic gradient in a temperate karst harbours exceptionally high diversity of soil Collembola. International Journal of Speleology 47: 247-262. https://doi.org/10.5038/1827-806X.47.2.2194

Ratnasingham S.\&HebertP.D.N.2007.BOLD:TheBarcode ofLife DataSystem(www.barcodinglife.org). Molecular Ecology Notes 7 (3): 355-364. https://doi.org/10.1111/j.1471-8286.2007.01678.x

Smiraglia C. \& Diolaiuti G. 2015. In: Azzoni R.S., Diolaiuti G. \& Smiraglia C. (eds). Il Nuovo Catasto dei Ghiacciai Italiani. Associazione Riconosciuta EvK2CNR, Bergamo, Italy.

Stevens M.I. \& D'Haese C.A. 2017. Morphologically tortured: taxonomic placement of an Antarctic springtail (Collembola: Isotomidae) misguided by morphology and ecology. Zoologica Scripta 46: 180187. https://doi.org/10.1111/zsc.12204

Stevens M.I., Fjellberg A., Greenslade P., Hogg I.D. \& Sunnucks P. 2006. Redescription of the Antarctic springtail Desoria klovstadi using morphological and molecular evidence. Polar Biology 29: 820-830. ttps://doi.org/10.1007/s00300-006-0120-y

Stoppani A. 1876. Il Bel Paese. Conversazioni sulle Bellezze naturali la Geologia e la Geografia fisica d'Italia. 
VALLE B. et al., A new species of cryophilic springtail (Collembola) from Italy

Valle B., Ambrosini R., Caccianiga M. \& Gobbi M. 2020. Ecology of the cold-adapted species Nebria germari (Coleoptera: Carabidae): the role of supraglacial stony debris as refugium during the current interglacial period. Acta Zoologica Academiae Scientiarum Hungaricae 66: 199-220. https://doi.org/10.17109/AZH.66.Suppl.199.2020

Zhang B., Chang L., Ni Z., Sun X. \& Wu D. 2017. Directional migration of three Desoria species (Collembola: Isotomidae) on the snow surface in late winter. European Journal of Soil Biology 81: 64-68. https://doi.org/10.1016/j.ejsobi.2017.06.009

Manuscript received: 13 August 2021

Manuscript accepted: 22 October 2021

Published on: 29 December 2021

Topic editor: Tony Robillard

Desk editor: Fariza Sissi

Printed versions of all papers are also deposited in the libraries of the institutes that are members of the EJT consortium: Muséum national d'histoire naturelle, Paris, France; Meise Botanic Garden, Belgium; Royal Museum for Central Africa, Tervuren, Belgium; Royal Belgian Institute of Natural Sciences, Brussels, Belgium; Natural History Museum of Denmark, Copenhagen, Denmark; Naturalis Biodiversity Center, Leiden, the Netherlands; Museo Nacional de Ciencias Naturales-CSIC, Madrid, Spain; Real Jardín Botánico de Madrid CSIC, Spain; Zoological Research Museum Alexander Koenig, Bonn, Germany; National Museum, Prague, Czech Republic. 
Appendix 1A. Calderone glacier, lower tongue mostly covered by stony debris. Photo taken on 8 Jul. 2020, when there was still a high snow cover. Red arrows indicate the sampling points where Desoria calderonis sp. nov. was sampled with the flotation method.

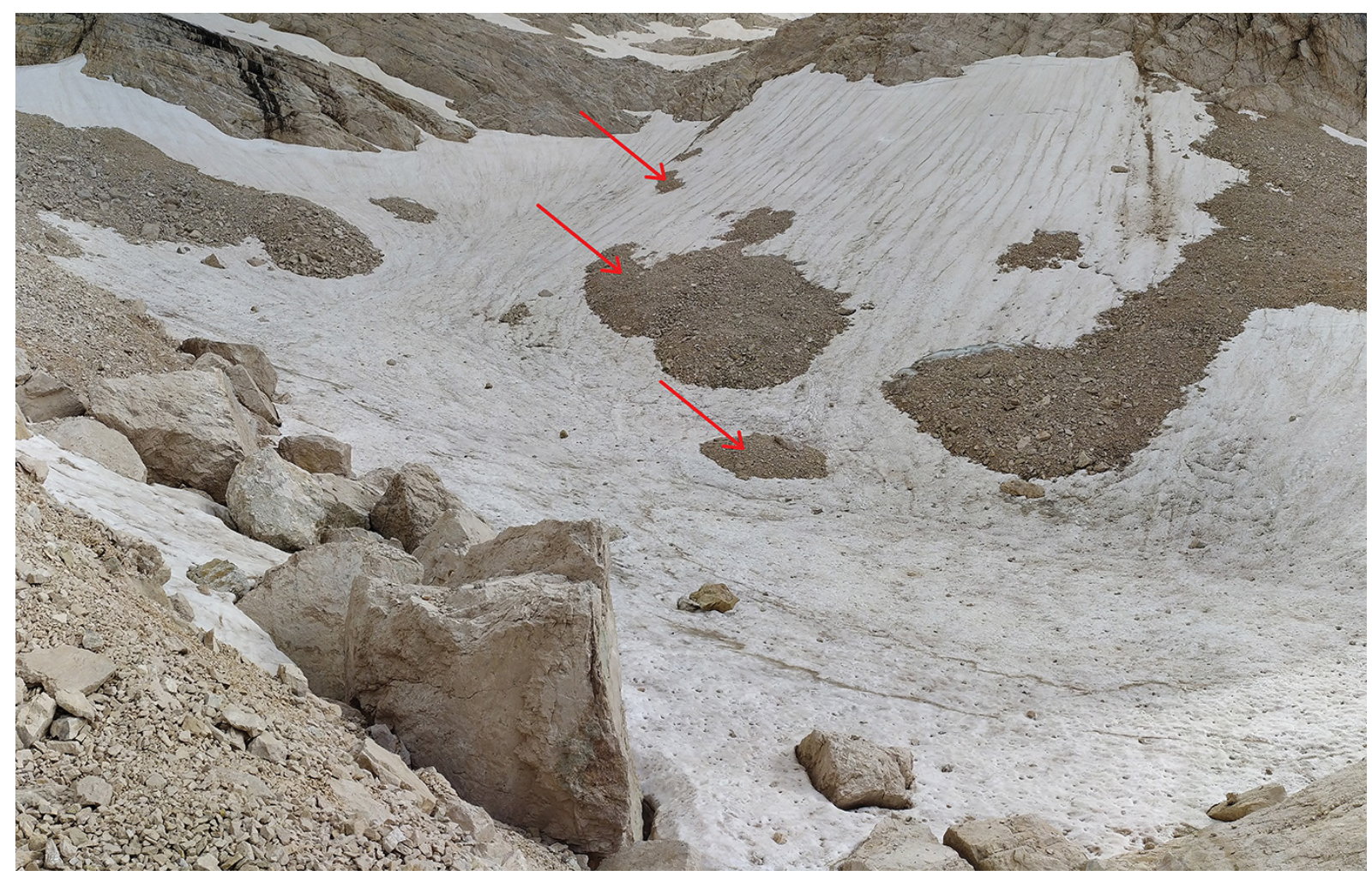

Appendix 1B. Supraglacial debris where $D$. calderonis sp. nov. was discovered. This is a coarse mineral soil in contact with the ice of the Calderone glacier: D. calderonis sp. nov. lives at the ice-stony debris interface. Red arrows indicate $D$. calderonis sp. nov. specimens moving on the ice and cold debris.

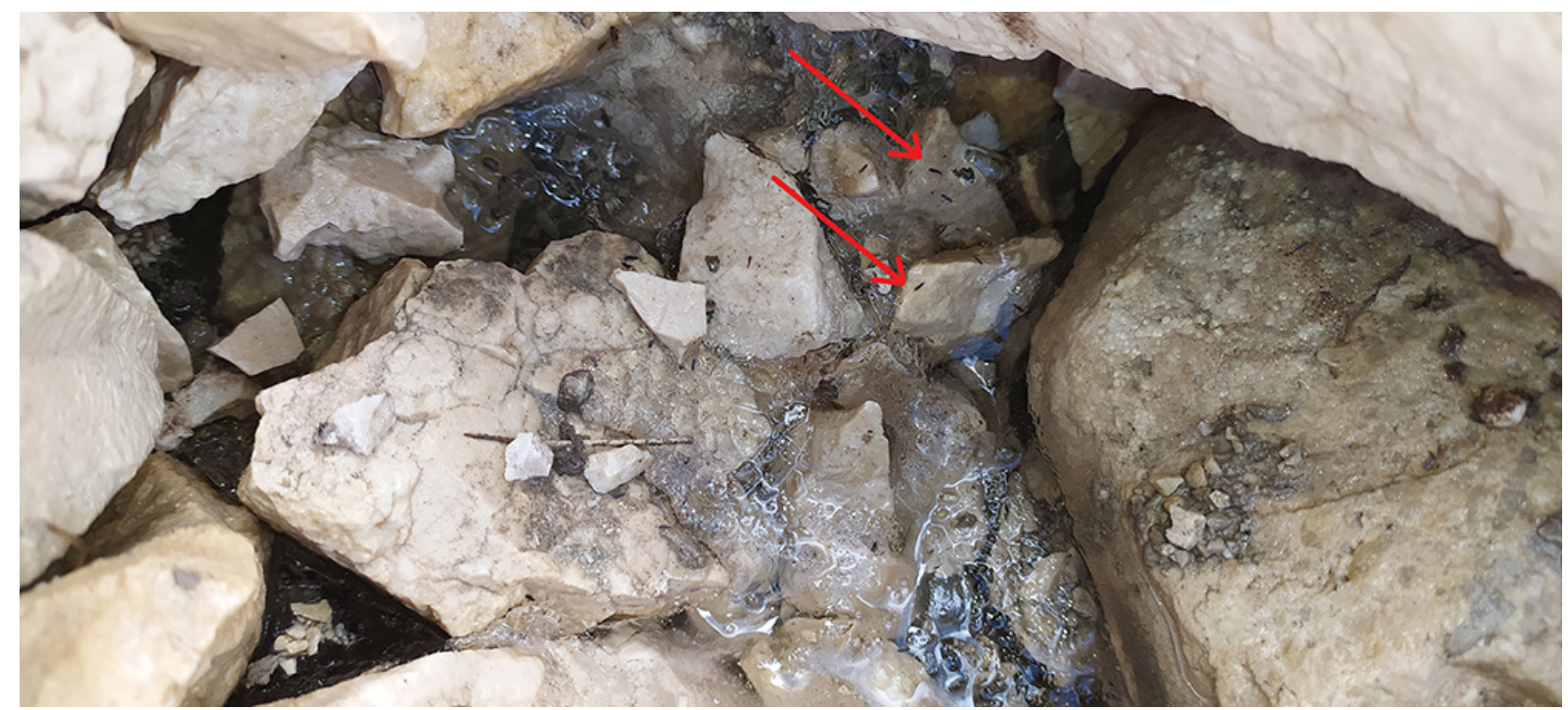

